\title{
Evaluation of the Risk Factors for Mechanical Failure of Intertrochanteric Femoral Fracture Treated with Intramedullary Nailing
}

\author{
İntramedüller Çivileme ile Tedavi Edilen İntertrokanterik Femur Kırıklarında Mekanik Yetmezliğe \\ Etki Eden Risk Faktörlerinin Değerlendirilmesi
}

\author{
Samet ERİNÇ \\ (1) 0000-0002-6494-6415 \\ Mustafa Hacı ÖZDEMIR \\ (D) 0000-0001-6189-3605
}

Department of Orthopedics and Traumatology, Şişli Hamidiye Etfal Research and Training Hospital, İstanbul, Turkey

\begin{abstract}
Aim: The aim of this study was to evaluate the radiological and clinical risk factors predisposing the proximal lag screw to mechanical failure in patients with pertrochanteric femur fractures treated with intramedullary nailing.

Material and Methods: All intertrochanteric fracture cases were evaluated retrospectively and 298 patients ( 24 had mechanical failure) were included in this study. The patients were compared in terms of demographic data, Singh index, reduction quality according to the Baumgaertner scale, proximal lag screw position according to Cleveland-Bosworth quadrants and the Parker ratio, and the calcar femorale restoration and tip-apex distance.

Results: There was no statistically significant difference in terms of gender $(\mathrm{p}=0.745)$, age $(\mathrm{p}=0.848)$, American Society of Anesthesiology scores $(\mathrm{p}=0.725)$, body mass index $(\mathrm{p}=0.648)$ and Singh index $(\mathrm{p}=0.119)$ between the two groups. There were statistically significant differences between the two groups in terms of the following variables; number of patients with unstable fracture $(\mathrm{p}<0.001)$, poor reduction quality $(\mathrm{p}<0.001)$, calcar femorale discontinuity $(\mathrm{p}<0.001)$, center-center/center-inferior lag screw position $(\mathrm{p}<0.001)$, and Parker ratio on the lateral view $(\mathrm{p}=0.002)$. The center-center/center-inferior lag screw position, good reduction quality and calcar femorale restoration were found to be parameters predicting superior outcomes according to logistic regression analyses.

Conclusion: From the results of this study, it was concluded that although the preoperative reduction of the fracture and tip-apex distance are mandatory to prevent failure of the proximal lag screw, posteromedial discontinuity and lag screw position have a vital role in the treatment of interochanteric femur fracture fixed with intramedullary nailing.
\end{abstract}

Keywords: Intertrochanteric femoral fracture; intramedullary nailing; proximal femoral nailing.

\section{ÖZ}

Amaç: Bu çalışmanın amacı intramedüller çivileme ile tedavi edilen pertrokanterik femur kırıklı hastalarda proksimal çektirme vidasının mekanik yetmezliğine sebep olabilecek radyolojik ve klinik risk faktörlerini değerlendirmektir.

Gereç ve Yöntemler: Tüm intertrokanterik kırık vakaları retrospektif olarak değerlendirildi ve 24'ünde mekanik yetmezliği olan 298 hasta bu çalışmaya dahil edildi. Hastalar, demografik veriler, Singh indeksi, Baumgartner skalasına göre redüksiyon kalitesi, Cleveland-Bosworth kadranlarına ve Parker oranı göre proksimal çektirme vida pozisyonu, femoral kalkarın restorasyonu ve tip-apeks mesafesi açısından karşılaştırıldı.

Bulgular: İki grup arasında cinsiyet $(\mathrm{p}=0.745)$, yaş $(\mathrm{p}=0.848)$, Amerikan Anesteziyoloji Derneği (American Society of Anesthesiology) skorları $(\mathrm{p}=0.725)$, vücut kitle indeksi $(\mathrm{p}=0.648)$ ve Singh indeksi $(\mathrm{p}=0.119)$ açısından istatistiksel olarak anlamlı bir farklılık yoktu. Aşağıdaki değişkenler açısından iki grup arasında istatistiksel olarak anlamlı farklılıklar vardı; stabil olmayan kırığı olan hasta sayısı $(p<0,001)$, kötü redüksiyon kalitesi $(p<0,001)$, femoral kalkar restorasyonu $(\mathrm{p}<0,001)$, merkez-merkez/merkez-alt çektirme vidası pozisyonu $(p<0,001)$ ve lateral görünümde Parker oranı $(p=0,002)$. Lojistik regresyon analizine göre merkez-merkez/merkez-alt çektirme vidası pozisyonu, iyi redüksiyon kalitesi ve femoral kalkar restorasyonunun üstün sonuçları öngören parametreler olduğu saptandı.

Sonuç: Bu çalışmanın sonuçlarından; proksimal çektirme vidasının mekanik yetmezliğinin önlenebilmesi için kırığın redüksiyon kalitesine ve uç-apeks mesafesine dikkat edilmesinin zorunlu olması ile birlikte, intramedüller çivileme ile sabitlenen interochanterik femur kırığ tedavisinde posteromedial kalkar restorasyonunun ve çektirme vidasının femur başı içindeki konumunun ciddi bir role sahip olduğu sonucuna varıldı.

Received / Gelis Tarihi : 04.10 Accepted / Kabul Tarihi : 01.12.2021 Available Online / Anahtar kelimeler: Intertrokanterik femoral kırı; intrameduller çivileme; proksimal femoral çivileme. 


\section{INTRODUCTION}

Osteoporotic hip fractures are one of the major health problems in the growing elderly population worldwide. In the 2000s, the estimated number of osteoporotic fractures throughout the world was 9 million, of which 1.9 million were hip fractures (1). Pertrochanteric femur fractures, which comprise half of all hip fractures, occur between the extracapsular segment of the femoral neck and the distal segment of the lesser trochanter (2). The high mortality and morbidity rates of patients with hip fractures necessitate the successful treatment of these types of fractures.

Selection of the fixation method and device depends on the fracture behavior, which may be stable or unstable. There is a general tendency to use an intramedullary nail for the treatment of an unstable intertrochanteric femur fracture. Intramedullary nails prevent the mechanical failure of unstable fractures which have a severely comminuted medial wall and/or a reverse oblique fracture line. Other mechanical advantages of the nails are the provision of a buttress effect when the lateral wall is missing and resistance to medialization of the proximal fragment. Many prospective randomized trials have shown better preservation of the reduction with intramedullary nails (3-5). However, proper reduction and correct application of the proximal femoral nail have a vital role in preventing complications. Mechanical failure after proximal femoral nailing remains a major complication with rates of $4-14 \%(6,7)$. The most evaluated risk factors are tip-apex distance, reduction quality, and position of the proximal lag screw in the femoral head $(8,9)$.

The aim of this study was to evaluate the radiological and clinical risk factors predisposing the proximal lag screw to mechanical failure in patients with pertrochanteric femur fractures treated with intramedullary nailing.

\section{MATERIAL AND METHODS}

Approval for this retrospective study was granted by the Institutional Ethics Committee Board (11.02.2020/1431, Şişli Hamidiye Etfal Training and Research Hospital). A total of 586 consecutive patients were identified who were admitted to our clinic with a pertrochanteric femur fracture between January 2013 and January 2019. Exclusion criteria were age $>60$ years, fracture fixation other than cephalomedullary nailing, pathological fracture, multiple traumas, high energy trauma, mortality in the early postoperative period, and less than 6 months of regular follow-up examinations. After the application of exclusion criteria, 298 patients were found to be eligible for this study. Demographic data, American Society of Anesthesiology (ASA) scores, and Singh index values were collected from the hospital database.

Both pre-operative and post-operative radiographs were evaluated. The follow-up anteroposterior (AP) and lateral radiographs taken on postoperative day 1 , then at $1,3,6$, and 12 months were also evaluated. If there was no regular follow-up after 6 months, the last radiological examination was evaluated. The evaluations were made by two experienced orthopedic surgeons at the same time with consensus.

Reduction and internal fixation were performed in the supine position under fluoroscopic examination. No patient received an open reduction, and all fractures was reduced by closed fracture reduction techniques. For fixation, the proximal femoral nail system (Tasarimmed PN-1, Istanbul, Turkey) was used, which has lengths of 170,200 , and $230 \mathrm{~mm}$. All patients received the standard postoperative protocol of protected weight-bearing with a walker or walking stick immediately postoperatively, and gradual progression to full weight-bearing within 3 months.

The Arbeitsgemeinschaft für Osteosynthesefragen / Orthopaedic Trauma Association (AO/OTA) classification systems were used to classify the fractures. According to the Fracture and Dislocation Classification Compendium (2018), if the lateral wall thickness is $<20.5 \mathrm{~mm}$, which is measured from $3 \mathrm{~cm}$ below the innominate tubercle of the greater trochanter and angled $135^{\circ}$ upward to the fracture line (Figure 1), the fracture was considered an AO A2 type fracture (10). Reduction quality and posteromedial support were also evaluated. Reduction quality was classified as good if both of the following criteria were met; neck-shaft angle of $1250-1450$ on the AP view, <200 angulation on the lateral view and displacement of $<4 \mathrm{~mm}$ (11). Posteromedial support was determined according to bone to bone continuity on the postoperative $\mathrm{x}$-ray, loss of bone stock due to displaced trochanter minor fracture was determined as lack of posteromedial support (12, Figure 2). The tip-apex distance of the proximal lag screw was measured as described by Baumgaertner et al. (9) and proximal lag screw placement was analyzed according to Cleveland-Bosworth quadrants and Parker ratio (13, Figure 3).

The patients were separated into two groups; patients with screw cut-out as the failure group and patients with uneventful healing group as the control group. All the radiological parameters (described above), demographic data, Singh index for osteoporosis evaluation and ASA scores were examined in the analyses and compared between the two groups.

\section{Statistical Analyses}

Data obtained in the study were analyzed statistically using SPSS v.15.0 software. Mean, standard deviation, median, minimum, maximum values, frequency and percentage were used for descriptive statistics. Kolmogorov-Smirnov test was performed to examine normal distribution. Comparisons of two independent groups were made with the Mann-Whitney U test since the numerical variables did not meet the normal distribution. Categorical variables were compared with the Pearson chi-square and Fisher's exact test. Mechanical failure was used as a dependent variable in the multivariate logistic regression analyses. The independent covariates were reduction quality (good or poor), tip-apex distance, the presence of posteromedial continuity, lag screw location (at the center-center and inferior-center or not) and Singh index. The odds ratio and 95\% confidence intervals were calculated. Statistical significance level was accepted as $\mathrm{p}<0.05$.

\section{RESULTS}

Of the 298 patients, cut-out of the proximal lag screw was observed in $24(8 \%)$ patients. Cut-out was observed within 3 months postoperatively, especially immediately after full weight-bearing on the fractured side. There was no statistically significant difference in terms of gender, age, ASA scores, body mass index (BMI), and Singh index 


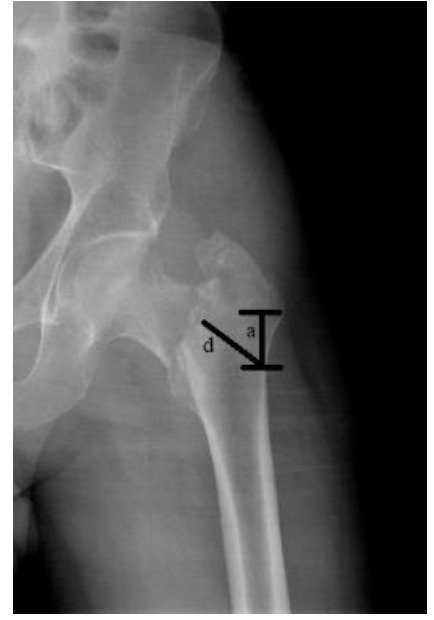

Figure 1.

Measurement of lateral wall thickness according to Arbeitsgemeinschaft für Osteosynthesefragen / Orthopaedic Trauma Association Fracture and Dislocation Classification Compendium (2018) $(\mathrm{a}=3 \mathrm{~cm}, \mathrm{~d}=$ lateral wall thickness)
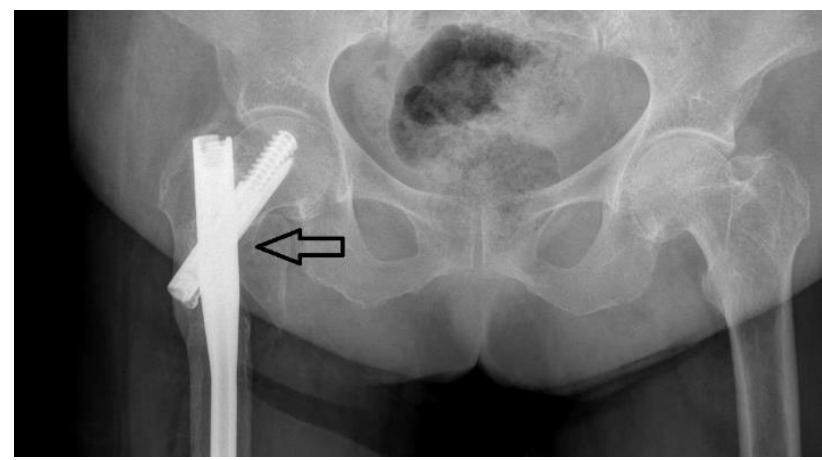

Figure 2. Lack of posteromedial support after fracture reduction

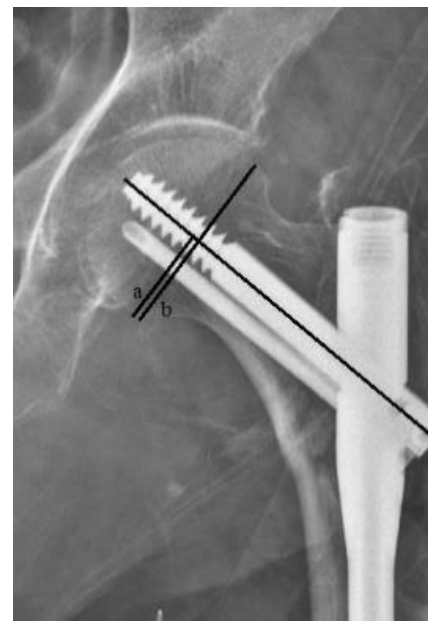

Figure 3.

Measurement of the

Parker ratio on the anteroposterior view $(\mathrm{a} / \mathrm{b} \times 100)$

between two groups (Table 1). There were 14 (58.4\%) female and $10(41.6 \%)$ male patients in the failure group and $141(51.5 \%)$ female, and $133(48.5 \%)$ male patients in the control group $(\mathrm{p}=0.745)$. The median age was 76.1 years in the failure group and 76.6 years in the control group ( $\mathrm{p}=0.848)$. The median Singh index score was 3 in both groups $(\mathrm{p}=0.119)$.

AO type 31-A1 fracture was determined in $128(46.7 \%)$ patients in the control group, and in $3(12.5 \%)$ patients in the failure group. AO type 31-A2 fracture, which implies lateral wall thickness $<20.5 \mathrm{~mm}$ was seen in $17(70.8 \%)$ patients in the failure group, and in $141(51.5 \%)$ patients in the control group. AO type 31-A3 fracture was determined in $4(16.7 \%)$ patients in the failure group, and in $5(1.8 \%)$ patients in the control group. There were statistically significant differences in the fracture types of the patients between the two groups $(\mathrm{p}<0.001$, Table 1$)$.

The median tip-apex distance was $15.5(12$ - 26) $\mathrm{mm}$ in the failure group and $14.4(8-28) \mathrm{mm}$ in the control group, and the difference was statistically significant $(\mathrm{p}=0.004)$. According to Cleveland-Bosworth quadrants, the lag screws were in the center-center / center-inferior (zone 5 and 8 ) of the femoral head in $12(50.0 \%)$ patients in the failure group (Table 2), and in 215 (78.5\%) patients in the control group (Table 3). There was a statistically significant difference between the two groups in terms of the distribution of the proximal lag screws according to Cleveland-Bosworth quadrants $(\mathrm{p}<0.001$, Table 1). The median Parker ratio was statistically significantly higher in the failure group than in the control group on lateral views $(0.51$ vs. $0.48, \mathrm{p}=0.002)$, but there was no statistically significant difference between the two groups on the AP views ( 0.48 vs. $0.49, \mathrm{p}=0.489)$.

When the reduction quality was assessed, poor reduction was seen in $9(37.5 \%)$ patients in the failure group and in $19(6.9 \%)$ patients in the control group, and the difference between the groups was statistically significant $(\mathrm{p}<0.001)$. The posteromedial cortical continuity was also evaluated with reduction quality and cortical discontinuity was found to be statistically higher in the failure group than in the control group $(\mathrm{p}<0.001$, Table 1$)$.

Multivariate logistic regression demonstrated that peripheral location of the lag screw (OR: 10.935; \%95 CI: 2.864-41.761, $\mathrm{p}<0.001$ ), reduction quality (OR: 6.544; $\% 95$ CI: 1.274-33.608, $\mathrm{p}=0.024)$, and posteromedial continuity (OR: 14.836; \%95 CI: 2.925-75.239, p=0.001), were the most important factors in the mechanical failure. According to the univariate analyses, the number of patients with unstable fracture and tip-apex distance was statistically higher in the failure group than in the control group, although no statistically significant difference was found in the multivariate analyses (Table 4).

\section{DISCUSSION}

The results of this study demonstrated that the peripheral location of the lag screw, posteromedial discontinuity and reduction quality were the most important factors in the cut-out risk of proximal lag screw. Mechanical failure was seen in $24(8 \%)$ patients, which was consistent with previous studies $(14,15)$. In the literature, it has been strongly advocated that the risk of mechanical failure increases with peripheral location of the femoral lag screw with higher tip-apex distance, although the risk decreases in patients with a proximal lag screw supported by the calcar femorale and located at the center-center (AP-lateral views) or inferior-center part of the femoral head $(16,17)$. One of the earlier studies on proximal femoral nails stated that the major factor influencing cut-out was lag screw position rather than tip-apex distance and the second distal quarter of the femoral head regarding middle central-neck axis was demonstrated as the 'safe zone' (14). In a cadaveric study, it was demonstrated that the inferior-center position of the lag screw provides better angular and rotational stability due to stronger support of the calcar femorale and posteromedial cortex than the other positions of the lag 
screw (17). In the current study, $50 \%(n=12)$ of the patients in the failure group had a lag screw in the center-center or inferior-center position, while in the control group the rate of lag screw in the center-center or inferior-center position was $78.5 \%(n=215)$. Furthermore, the Parker ratio on the lateral view was statistically significantly higher in the failure group than in the control group which implied more posterior positioning of the lag screw in the failure group (0.51 vs 0.48). Many studies have suggested that the posterior location of the proximal lag screw on the

Table 1. Comparison of demographic and clinical characteristics

\begin{tabular}{|c|c|c|c|}
\hline & Failure $(n=24)$ & Control $(n=274)$ & p \\
\hline Age, median (IQR) [min-max] & $76.1(10.7)[70-86]$ & $76.6(15.2)[41-109]$ & 0.848 \\
\hline \multicolumn{4}{|l|}{ Gender, n (\%) } \\
\hline Male & $10(41.6 \%)$ & $133(48.5 \%)$ & \multirow{2}{*}{0.745} \\
\hline Female & $14(58.4 \%)$ & $141(51.5 \%)$ & \\
\hline \multicolumn{4}{|l|}{ AO Type, n (\%) } \\
\hline A1 & $3(12.5 \%)$ & $128(46.7 \%)$ & \multirow{3}{*}{$<0.001$} \\
\hline $\mathrm{A} 2$ & $17(70.8 \%)$ & $141(51.5 \%)$ & \\
\hline A3 & $4(16.7 \%)$ & $5(1.8 \%)$ & \\
\hline Tip-Apex Distance, median (IQR) [min-max] & $15.5(7)[12-26]$ & $14.4(4)[8-28]$ & 0.004 \\
\hline \multicolumn{4}{|l|}{ Screw Placement, n (\%) } \\
\hline 1 & $0(0.0 \%)$ & $3(1.1 \%)$ & \multirow{9}{*}{$<0.001$} \\
\hline 2 & $3(12.5 \%)$ & $9(3.3 \%)$ & \\
\hline 3 & $3(12.5 \%)$ & $3(1.1 \%)$ & \\
\hline 4 & $2(8.4 \%)$ & $15(5.5 \%)$ & \\
\hline 5 & $11(45.8 \%)$ & $172(62.8 \%)$ & \\
\hline 6 & $3(12.5 \%)$ & $18(6.6 \%)$ & \\
\hline 7 & $1(4.2 \%)$ & $5(1.8 \%)$ & \\
\hline 8 & $1(4.2 \%)$ & $43(15.7 \%)$ & \\
\hline 9 & $0(0.0 \%)$ & $6(2.2 \%)$ & \\
\hline Parker Ratio (Lateral), median (IQR) [min-max] & $0.51(0.09)[0.41-0.72]$ & $0.48(0.10)[0.21-0.72]$ & 0.002 \\
\hline Parker Ratio (AP), median (IQR) [min-max] & $0.48(0.06)[0.12-0.72]$ & $0.49(0.05)[0.20-0.69]$ & 0.489 \\
\hline \multicolumn{4}{|l|}{ Reduction, $\mathrm{n}(\%)$} \\
\hline Good & $15(62.5 \%)$ & $255(93.1 \%)$ & \multirow{2}{*}{$<0.001$} \\
\hline Poor & $9(37.5 \%)$ & $19(6.9 \%)$ & \\
\hline \multicolumn{4}{|l|}{ PMC, n (\%) } \\
\hline Positive & $16(66.7 \%)$ & $268(97.8 \%)$ & \multirow{2}{*}{$<0.001$} \\
\hline Negative & $8(33.3 \%)$ & $6(2.2 \%)$ & \\
\hline ASA, median (IQR) [min-max] & $3(1)[2-4]$ & $3(1)[1-4]$ & 0.725 \\
\hline \multicolumn{4}{|l|}{ ASA, n $(\%)$} \\
\hline 1 & $0(0.0 \%)$ & $3(1.1 \%)$ & \multirow{4}{*}{0.701} \\
\hline 2 & $6(25.0 \%)$ & $88(32.1 \%)$ & \\
\hline 3 & $14(58.3 \%)$ & $126(46.0 \%)$ & \\
\hline 4 & $4(16.7 \%)$ & $57(20.8 \%)$ & \\
\hline Singh Index, median (IQR) [min-max] & $3(1)[2-4]$ & $3(2)[2-5]$ & 0.119 \\
\hline Body Mass Index, median (IQR) [min-max] & $23(3)$ [19-27] & $24(4)[15-28]$ & 0.648 \\
\hline \multicolumn{4}{|l|}{ Length of Nail, n (\%) } \\
\hline 170 & $2(8.3 \%)$ & $0(0.0 \%)$ & \multirow{3}{*}{0.102} \\
\hline 200 & $1(4.2 \%)$ & $66(24.1 \%)$ & \\
\hline 230 & $21(87.5 \%)$ & $208(75.9 \%)$ & \\
\hline
\end{tabular}

Table 2. The distribution of failed proximal lag screws according to Cleveland-Bosworth quadrants

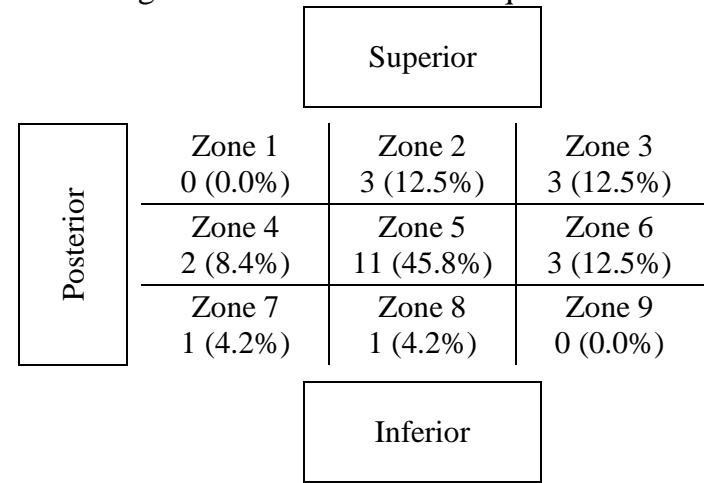

Table 3. The distribution of the proximal lag screws in the control group according to Cleveland-Bosworth quadrants

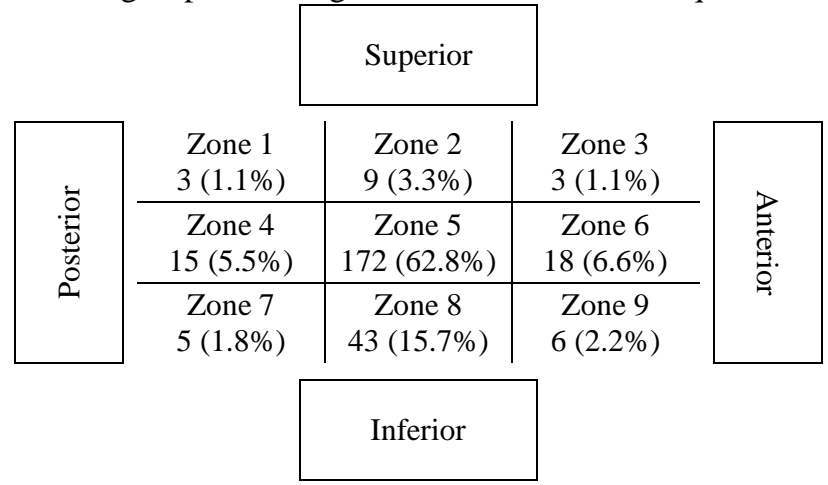


Table 4. Results of the logistic regression analysis

\begin{tabular}{lcc}
\hline & OR $(\mathbf{\% 9 5}$ CI $)$ & $\mathbf{p}$ \\
\hline Gender (Female) & $3.814(0.961-15.138$ & 0.057 \\
Screw Position (Peripheral) & $10.935(2.864-41.761)$ & $<\mathbf{0 . 0 0 1}$ \\
AO Type (A2) & $2.579(0.674-9.860)$ & 0.166 \\
AO Type (A3) & $10.024(1.018-98.696)$ & 0.068 \\
Reduction (Good) & $6.544(1.274-33.608)$ & $\mathbf{0 . 0 2 4}$ \\
PMC (Negative) & $14.836(2.925-75.239)$ & $\mathbf{0 . 0 0 1}$ \\
Tip-Apex Distance & $1.117(0.984-1.268)$ & 0.086 \\
Singh Index & $1.179(0.566-2.458)$ & 0.660 \\
\hline OR:
\end{tabular}

OR: odds ratio, $\mathrm{CI}$ : confidence interval, $\mathrm{AO}$ : Arbeitsgemeinschaft für Osteosynthesefragen, PMC: Posteriomedial continuity

lateral view with $>0.5$ Parker ratio was associated with higher tip-apex distance and an increased risk of mechanical failure, especially in unstable intertrochanteric femoral fractures $(18,19)$.

The importance of the tip-apex distance and proximal lag screw position in the femoral head have been demonstrated since the earliest reports of clinical and radiological outcomes of the intertrochanteric femoral fracture surgery (15). Baumgaertner et al. (9) described the tip-apex distance, which has become one of the most important factors in the treatment of intertrochanteric femoral fractures. It is generally accepted that a tip-apex distance $>20-25 \mathrm{~mm}$ increases the risk of mechanical failure. In this study, although the median tip-apex distance was $<25 \mathrm{~mm}$ in both groups, it was statistically significantly higher in the failure group. A more peripheral and posterior position of the proximal lag screw may have caused the higher tip-apex distance in the failure group (11).

Under axial loading, the calcar femorale redistributes the stress, and consequently, disruption of the calcar femorale results in collapse and varus displacement with axial loading of the femur (20). In 1949, Evans EM. (21) first emphasized the importance of providing posteromedial cortical continuity, otherwise, an unstable fracture will collapse into varus and rotational instability will occur after fixation of the femur. Many previous studies have reported that medial calcar discontinuity may lead to poor bone healing and mechanical failure. Furthermore, establishment of the medial calcar support has been linked to superior outcomes in the treatment of unstable intertrochanteric femoral fractures (22). Liang et al. (23) demonstrated that the highest stress occurred at the calcar femorale under axial loading. In another study, loss of posteromedial support was demonstrated as an independent factor for mechanical failure in unstable intertrochanteric fractures. Recently, fixation of the lesser tubercle has been advocated in patients with medial calcar discontinuity $(24,25)$. In the current study, good reduction and posteromedial continuity were correlated with uneventful healing of the intertrochanteric femoral fracture. Loss of posteromedial continuity was found in $33.3 \%(n=8)$ of the patients in the failure group, although the rate was $2.2 \%(n=6)$ in the patients with uneventful healing and the poor reduction was observed in $9(37.5 \%)$ patients in the failure group, while in $19(6.9 \%)$ patients in the control group.
Lateral wall integrity and a superolateral buttress are also essential to provide mechanical stability in intertrochanteric fractures. An intact lateral wall prevents the excessive collapse and medialization of the distal fragment. $(26,27)$. Tan et al. (28) conducted a study on the morphology and pitfalls of an unstable intertrochanteric femur fracture variant which was not well recognized in the existing classification systems. It was reported that the lack of a superolateral buttress was the main contributory factor to mechanical failure rather than medial calcar buttress. Another study by Tawari et al. (29) suggested that the existing fracture classifications, which classify fractures according to posteromedial comminution and the direction of the fracture line, are insufficient. Han et al. (30) proposed a comprehensive radiological examination including AP, lateral, and traction internal rotation views. It was suggested that 3D-CT should be obtained before any intervention in cases of highly comminuted fracture, and the type of lateral wall fracture according to the CT scan should be accepted for the classification of the fracture. In 2018, the Fracture and Dislocation Classification Compendium revised the AO classification of intertrochanteric fractures and emphasized the lateral wall thickness. The revised system separates pertrochanteric fractures as A1 or A2 according to the severity of the greater trochanteric fragmentation and lateral wall thickness. In this study, $70.8 \%(n=17)$ of the patients had type $\mathrm{A} 2$, and $16.7 \%(\mathrm{n}=4)$ had type $\mathrm{A} 3$ fracture in the failure group, whereas these rates were $51.5 \%(n=141)$ and $1.8 \%(\mathrm{n}=5)$ respectively in the control group. It was assumed that insufficiency in the lateral wall and entry point bone stock may cause lateralization of the nail and incorrect peripheral lag screw placement. In addition, lack of trochanteric stability and lateral wall integrity may lead to malreduction of the fracture intraoperatively or loss of reduction postoperatively (31). Yuan et al. (32) suggested using a supporting mini locking plate for fixation of the trochanter major fragment in the intramedullary nailing of pertrochanteric fractures. Kulkarni et al. (33) evaluated 154 patients with an unstable intertrochanteric fracture and suggested lateral wall reconstruction with a cerclage wire in patients with fragmented trochanter major and lateral wall. The mechanical failure rate was $7.8 \%$ in that study, but no cut-out was found in the patients with reconstructed lateral wall.

Osteoporosis has also been evaluated as a factor predicting mechanical failure. Akan et al. (34) found lower Harris hip scores after intramedullary femoral nailing surgery for intertrochanteric fracture in patients with high-grade osteoporosis (Singh index III-IV) compared to those with low-grade osteoporosis (Singh index III-IV). Barrios et al. (35) suggested that osteoporosis is one of the major factors for mechanical failure after intramedullary nailing surgery. In the current study, no statistically significant difference was found between the two groups in respect of osteoporosis.

The major limitation of this study was that although the patient follow-up examination findings were recorded prospectively, the study was conducted as a retrospective, non-controlled study. In addition, bone mineral density, which may be associated with bone fragility, was not examined and the sample size in the subgroups was small. 


\section{CONCLUSION}

From the results of this study, it was concluded that although the preoperative reduction of the fracture and tip-apex distance are mandatory to prevent failure of the proximal lag screw, posteromedial discontinuity and lag screw position have a vital role in the treatment of interochanteric femur fractures fixed with intramedullary nailing. Furthermore, it can be emphasized that a lack of mechanical support at the entry point of the intramedullary nail and a severely comminuted pertrochanteric area should be considered important factors in the treatment of pertrochanteric femur fractures with intramedullary nailing.

Ethics Committee Approval: The study was approved by the Ethics Committee of Şişli Hamidiye Etfal Training and Research Hospital (11.02.2020, 1431).

Conflict of Interest: None declared by the authors.

Financial Disclosure: None declared by the authors.

Acknowledgements: None declared by the authors.

Author Contributions: Idea/Concept: SE, HMÖ; Design: SE, HMÖ; Data Collection/Processing: SE; Analysis/Interpretation: SE, HMÖ; Literature Review: SE; Drafting/Writing: SE; Critical Review: HMÖ.

\section{REFERENCES}

1. Johnell O, Kanis JA. An estimate of the worldwide prevalence and disability associated with osteoporotic fractures. Osteoporos Int. 2006;17(12):1726-33.

2. Schipper IB, Steyerberg EW, Castelein RM, van Vugt AB. Reliability of the AO/ASIF classification for pertrochanteric femoral fractures. Acta Orthop Scand. 2001;72(1):36-41.

3. Baldwin PC 3rd, Lavender RC, Sanders R, Koval KJ. Controversies in intramedullary fixation for intertrochanteric hip fractures. J Orthop Trauma. 2016;30(12):635-41.

4. Hardy DC, Descamps PY, Krallis P, Fabeck L, Smets $\mathrm{P}$, Bertens CL, et al. Use of an intramedullary hipscrew compared with a compression hip-screw with a plate for intertrochanteric femoral fractures. A prospective, randomized study of one hundred patients. J Bone Joint Surg Am. 1998;80(5):618-30.

5. Pajarinen J, Lindahl J, Savolainen V, Michelsson O, Hirvensalo E. Femoral shaft medialisation and neckshaft angle in unstable pertrochanteric femoral fractures. Int Orthop. 2004;28(6):347-53.

6. Jiamton C, Boernert K, Babst R, Beeres FJP, Link BC. The nail-shaft-axis of the of proximal femoral nail antirotation (PFNA) is an important prognostic factor in the operative treatment of intertrochanteric fractures. Arch Orthop Trauma Surg. 2018;138(3):339-49.

7. Geller JA, Saifi C, Morrison TA, Macaulay W. Tipapex distance of intramedullary devices as a predictor of cut-out failure in the treatment of peritrochanteric elderly hip fractures. Int Orthop. 2010;34(5):719-22.
8. Yam M, Chawla A, Kwek E. Rewriting the tip apex distance for the proximal femoral nail anti-rotation. Injury. 2017;48(8):1843-7.

9. Baumgaertner MR, Curtin SL, Lindskog DM, Keggi JM. The value of the tip-apex distance in predicting failure of fixation of peritrochanteric fractures of the hip. J Bone Joint Surg Am. 1995;77(7):1058-64.

10. Meinberg EG, Agel J, Roberts CS, Karam MD, Kellam JF. Fracture and Dislocation Classification Compendium2018. J Orthop Trauma. 2018;32(Suppl 1):S1-170.

11. Hsueh KK, Fang CK, Chen CM, Su YP, Wu HF, Chiu FY. Risk factors in cutout of sliding hip screw in intertrochanteric fractures: an evaluation of 937 patients. Int Orthop. 2010;34(8):1273-6.

12. Ye KF, Xing Y, Sun C, Cui ZY, Zhou F, Ji HQ, et al. Loss of the posteromedial support: a risk factor for implant failure after fixation of $\mathrm{AO}$ 31-A2 intertrochanteric fractures. Chin Med J. 2020;133(1):41-8.

13. Cleveland M, Bosworth DM, Thompson FR, Wilson HJ Jr, Ishizuka T. A ten-year analysis of intertrochanteric fractures of the femur. J Bone Joint Surg Am. 1959;41-A:1399-408.

14. Herman A, Landau Y, Gutman G, Ougortsin V, Chechick A, Shazar N. Radiological evaluation of intertrochanteric fracture fixation by the proximal femoral nail. Injury. 2012;43(6):856-63.

15. Rubio-Avila J, Madden K, Simunovic N, Bhandari M. Tip to apex distance in femoral intertrochanteric fractures: a systematic review. J Orthop Sci. 2013;18(4):592-8.

16. Güven M, Yavuz U, Kadığlu B, Akman B, Kılınçoğlu $\mathrm{V}$, Ünay $\mathrm{K}$, et al. Importance of screw position in intertrochanteric femoral fractures treated by dynamic hip screw. Orthop Traumatol Surg Res. 2010;96(1):21-7.

17. Hwang JH, Garg AK, Oh JK, Oh CW, Lee SJ, MyungRae C, et al. A biomechanical evaluation of proximal femoral nail antirotation with respect to helical blade position in femoral head: A cadaveric study. Indian $\mathbf{J}$ Orthop. 2012;46(6):627-32.

18. Turgut A, Kalenderer Ö, Karapınar L, Kumbaracı M, Akkan HA, Ağuş H. Which factor is most important for occurrence of cutout complications in patients treated with proximal femoral nail antirotation? Retrospective analysis of 298 patients. Arch Orthop Trauma Surg. 2016;136(5):623-30.

19. Zhang W, Antony Xavier RP, Decruz J, Chen YD, Park DH. Risk factors for mechanical failure of intertrochanteric fractures after fixation with proximal femoral nail antirotation (PFNA II): a study in a Southeast Asian population. Arch Orthop Trauma Surg. 2021;141(4):569-75.

20. Zhang Q, Chen W, Liu H, Li ZY, Song ZH, Pan JS, et al. The role of the calcar femorale in stress distribution in the proximal femur. Orthop Surg. 2009;1(4):311-6.

21. Evans EM. The treatment of trochanteric fractures of the femur. J Bone Joint Surg Br. 1949;31B(2):190-203.

22. Chang SM, Zhang YQ, Ma Z, Li Q, Dargel J, Eysel P. Fracture reduction with positive medial cortical support: a key element in stability reconstruction for the unstable pertrochanteric hip fractures. Arch Orthop Trauma Surg. 2015;135(6):811-8. 
23. Liang C, Peng R, Jiang N, Xie G, Wang L, Yu B. Intertrochanteric fracture: Association between the coronal position of the lag screw and stress distribution. Asian J Surg. 2018;41(3):241-9.

24. Puram C, Pradhan C, Patil A, Sodhai V, Sancheti P, Shyam A. Outcomes of dynamic hip screw augmented with trochanteric wiring for treatment of unstable type A2 intertrochanteric femur fractures. Injury. 2017;48(Suppl 2):S72-7.

25. Kim GM, Nam KW, Seo KB, Lim C, Kim J, Park YG. Wiring technique for lesser trochanter fixation in proximal IM nailing of unstable intertrochanteric fractures: A modified candy-package wiring technique. Injury. 2017;48(2):406-13.

26. Haidukewych GJ, Israel TA, Berry DJ. Reverse obliquity fractures of the intertrochanteric region of the femur. J Bone Joint Surg Am. 2001;83(5):643-50.

27. Hsu CE, Shih CM, Wang CC, Huang KC. Lateral femoral wall thickness. A reliable predictor of postoperative lateral wall fracture in intertrochanteric fractures. Bone Joint J. 2013;95-B(8):1134-8.

28. Tan BY, Lau AC, Kwek EB. Morphology and fixation pitfalls of a highly unstable intertrochanteric fracture variant. J Orthop Surg (Hong Kong). 2015;23(2):1425.

29. Tawari AA, Kempegowda H, Suk M, Horwitz DS. What makes an intertrochanteric fracture unstable in
2015? Does the lateral wall play a role in the decision matrix? J Orthop Trauma. 2015;29(Suppl 4):S4-9.

30. Han SK, Lee BY, Kim YS, Choi NY. Usefulness of multi-detector CT in Boyd-Griffin type 2 intertrochanteric fractures with clinical correlation. Skeletal Radiol. 2010;39(6):543-9.

31. Gotfried Y. Integrity of the lateral femoral wall in intertrochanteric hip fractures: an important predictor of a reoperation. $\mathrm{J}$ Bone Joint Surg Am. 2007;89(11):2552-3.

32. Yun HH, Lee YI, Kim KH, Yun SH. Use of auxiliary locking plates for the treatment of unstable pertrochanteric femur fractures. Orthopedics. 2015;38(5):305-9.

33. Kulkarni SG, Babhulkar SS, Kulkarni SM, Kulkarni GS, Kulkarni MS, Patil R. Augmentation of intramedullary nailing in unstable intertrochanteric fractures using cerclage wire and lag screws: a comparative study. Injury. 2017;48(Suppl 2):S18-22.

34. Akan K, Cift H, Ozkan K, Eceviz E, Tasyikan L, Eren A. Effect of osteoporosis on clinical outcomes in intertrochanteric hip fractures treated with a proximal femoral nail. J Int Med Res. 2011;39(3):857-65.

35. Barrios C, Broström LA, Stark A, Walheim G. Healing complications after internal fixation of trochanteric hip fractures: the prognostic value of osteoporosis. J Orthop Trauma. 1993;7(5):438-42. 